\title{
The Determinants of Shopping Shifts from Alfamart and Indomart to 212 Mart in Batam Sub District (Study of Female Customers Shopping at 212 Mart)
}

\author{
$1^{\text {st }}$ Dewi \\ Departement Business Mangement \\ Batam State Polytechnic \\ Batam, Kepulauan Riau Indonesia \\ ayudiradewi@gmail.com
}

\author{
$2^{\text {nd }}$ Shinta Wahyu Hati \\ Departement Business Mangement \\ Batam State Polytechnic \\ Batam, Kepulauan Riau Indonesia \\ shinta@polibatam.ac.id
}

\begin{abstract}
This study aims to find out what factors influence Indomaret and Alfamart customers switching services to minimarket 212 Mart. Samples were taken by purposive sampling method with a total sample of 100 people. Data collection techniques using questionnaires and tested using factor analysis techniques. The results of this study indicate that out of 24 factors there are 8 factors that influence the shift of spending from the Indomaret and Alfamart minimarkets to minimarket 212 Mart in Batam Kota District, namely: Factors in the nature of goods, price factors, and failure in service, reliability factor of price suitability, inconvenience, accidental factors and location proximity factors.
\end{abstract}

Keywords-Factor Analysis, Brand Switching, Minimarket.

\section{A. Background}

\section{INTRODUCTION}

A factor that attracts customers to shop in modern retail is a cheap and affordable price and merchandise availability. The common strategies implemented by Minimarket retailers should be able to provide diversity of merchandise offered to customers. According to ${ }^{[3]}$, the completeness of categories and brands of goods sold, the management of merchandise and the availability of adequate goods, will give a sense of selfsatisfaction to customers, encouraging customers to shop again. To provide satisfaction to customers, retailers must be able to provide goods or services with the best quality as well as a decent price according to what the customer expects. Retail business or retail businesses are growing very rapidly in Indonesia in recent years. The progress of the retail business in Indonesia is influenced by the development of the manufacturing business as well as market opportunities that are open enough due to the high economic.

Alfamart and Indomaret retail minimarket is a type of aggressive modern market by increasing the number of outlets and implementing franchise system. In addition, the distance between Indomaret and Alfamart is close to the side. This makes the competition fast enough to be balanced with the knowledge of retailers in order to adapt to the improvement of the strategy in retail business to increase the scale.

The wide choice of people over the retail increasingly encourages the increasing number of retailers both in terms of brands and numbers. This is evident from the many modern retail business that have begun to grow rapidly in recent years, such as the retail format of Alfamart Minimarket, Indomaret, 212 Mart, and private owned minimarket.

B. Formulation of the problem

The Formulations in this study are as follows:

1. A shopping drift from Indomaret and Alfamart minimarket to 212 Mart minimarkets.

2. What are the factors that determine the shifting shopping from convenience stores Indomaret and Alfamart from convenience stores Indomaret and Alfamart to Minimarket 212 Mart.

C. Significance of the study

There are two benefits in this study, namely:

1) Practical Benefits

For Minimarket 212 Mart, this research is expected to provide input to Minimarket 212 Mart in determining retail management and retail marketing policies.

2) Theoretical benefits

a. For readers

Results of this study are expected to be able to add information and knowledge as a comparison for future research, so that it can correct any shortcomings in this study.

b. For the writer

The results of this study are expected to increase knowledge and insight, especially in terms of shifting consumer spending. 


\section{REVIEW OF LITERATURE}

\section{A. Theoretical Study}

Retail mix according to ${ }^{[12]}$ Retail blend is a marketing strategy that refers to several variables, where by retailers can combine these variables into alternative avenues in an effort to attract consumers. ${ }^{[9]}$ stated that there are six elements of retail mix to be considered: product diversity (product), pricing in each product (price), strategic location (place), introducing the brand to the consumer (Promotion), process of service and sales (personnel), and in-store atmosphere that determines consumer decision in shopping (presentation).

According to ${ }^{[12]}$, the product is the entire offer made by the company to consumers in serving consumers, naming merchandise and store locations, factors that must be considered a store or department store in Product determinations of variety, width, consistency, and balance.

\section{1) Promotion}

According to ${ }^{[12]}$, Sales promotion is a retail business that aims to encourage increased sales in the form of promotional programs.

\section{2) Service}

According to ${ }^{[12]}$, service is a desire of consumers to be served, and the service is certainly related to the sale of products that will be purchased by consumers. Services defined as activities, benefits, satisfaction of a offered in sales. Employers should adapt the types of services offered with other elements in the retail mix.

\section{3) Physical facilities}

Physical facilities are determinants in dominating the market share desired by the company, because market mastery can be achieved if the company gets a good position so that it can create an image Company for its customers.

\section{4) Brand Switching}

Brand Switching is a time when a customer or group of customers move loyalty from one brand to a certain product to another product brand ${ }^{[10]}$.

Causes of Consumer Switching. According to ${ }^{[1]}$, there are 8 variables that affect consumer switching, namely:

\section{a. Price}

Pricing decisions are very meaningful in determining value for consumers. The customer will feel the cost or price charged to him is high if the benefits he receives are lower. If this happens, the customer will feel aggrieved, dissatisfied and there will arise a desire to switch to another service provider that is felt to be able to fulfill his expectations.

\section{b. Inconveniences}

Inconvenience is one of the factors that causes consumers to move to other service companies. Own inconvenience caused by easy access to achievement and strategic location, comfort felt by consumers, this includes: parking areas, instore layouts and shop cleanliness.

\section{c. Core service failure}

For service providers very important to maintain the quality of service in order to provide satisfaction to users. service delivery will be directly felt by the user. The core service failures factor is one of the factors that causes consumers to move to other companies.

\section{d. Service Encounter Failures}

The factor of service encounter failures is the personal interaction between customers and employees is one of the factors that causes consumers to move to other companies.

e. Response to service failure

The response factor for service failure (response to service failures) is the occurrence of consumer displacement due to the failure of service providers in handling situations that occur.

\section{f. Attraction by competitor}

Attraction by competitors emphasize the perception of what attracts consumers to make shopping shifts, almost similar to the brand image that gives consumers certain reasons for making purchases at certain service providers.

\section{g. Ethical problems}

Ethical problems (Ethical problems) are problems that are related to morality, insecurity and inconvenience. According to $^{[7]}$, the author of the book Moral Intelligence, argues that companies that have leaders who apply high ethical and moral standards have proven to be more successful in the long run.

\section{h. Involuntary switching}

Buying decision According to ${ }^{[8]}$, suggest that purchasing decisions are the stage of the decision process where the actual consumer purchases the product.

\section{B. Framework}

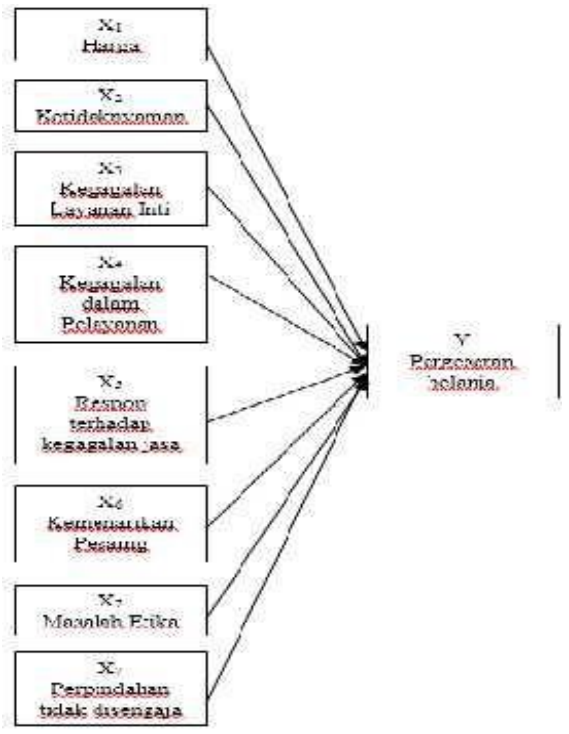

Fig. 1. Framework 


\section{RESEARCH METHODS}

\section{Design and Object Research}

The type of research used in this research is quantitative descriptive research. According to [11], descriptive understanding is a method that serve to describe or give an overview of the object under study through data or sample that have been collected as they are, without analyzing and making general conclusions. The object of this research is female customers who shop at the 212 Mart minimarkets Anggrek Sari branch located in Batam Center.

\section{RESULTS AND DISCUSSION}

\section{A. General description of the company}

Starting from the 212 actions in December2016, the National Fatwa Guards Movement (GNPF) of the Indonesian Ulema Council (MUI) initiated the Establishment of the Sharia Cooperative 212 which then officially launched mass registration through online channels on January 20, 2017 in Sentul, Bogor.

212 Mart especially in Batam City, the first time in the Legend Area which is located at Jl. Legend Park Housing Hangtuah Blok A2 No. 10, Batam Center.

\section{Validity and Reliability Validity}

According to ${ }^{[11]}$, Validity test is the extent to which a measuring instrument shows accuracy and suitability. To see whether a measuring instrument is reliable or not, a statistical approach is used, namely through the reliability coefficient and if the reliability coefficient is 0.6 , then the statement is stated to be reliable (reliable).

$$
\mathrm{R}_{\mathrm{xy}}=\frac{n x-\sum x\left(\sum y\right)\left(\sum\right)}{\sqrt{\left\{\sum X^{-}-\left(\sum x \mp\right)\left(n \sum \gamma^{-}-\left(\sum\right)^{3}\right)\right.}}
$$

Information:

Rxy $=$ Correlation coefficient between variables

$\sum x y=$ Number of multiplication $x y$

$\sum x=$ Number of variable values $x$

$\sum y=$ Number of variable values $y$

$\sum \mathrm{x} 2=$ Number of powers of the value $\mathrm{x}$

$\sum \mathrm{y} 2=$ Number of powers of two $\mathrm{y}$ values

$\mathrm{N}=\quad$ Number of samples

\section{Reliability}

According to ${ }^{[5]}$, the reliability values of the indicators / item statements received questionnaires can be searched using the Cronbach Alpha formula. The formula for calculating reliability is as follows:

$$
\mathrm{R} 11=\left(\frac{n}{n-1}\right)\left(1-\frac{\sum s_{i}^{*}}{s_{i}^{2}}\right)
$$

Where :
$\mathrm{R}=$ instrument reliability coefficient $\mathrm{n}=$ number of items

$s i=$ variance score of the $i$-question $s t=$ total variance score

According to ${ }^{[6]}$, the criteria for an indicator/ item statement questionnaire are declared reliable if the alpha value is greater than 0.60 .

B. Research Results and Discussion Factor Analysis Kaiser-Meyer-Olkin dan Barlett's Test

TABLE I. KMO AND BARTLETT'S TEST

\begin{tabular}{|c|c|}
\hline $\begin{array}{c}\text { Kaiser-Meyer-Olkin Measure of Sampling } \\
\text { Adequacy. }\end{array}$ & $\mathbf{. 7 1 5}$ \\
\hline Approx. Chi- & 1192.0 \\
\hline Bartlett's Test of Square & 95 \\
\hline Sphericity Df & 276 \\
\hline Sig. & $\mathbf{. 0 0 0}$ \\
\hline
\end{tabular}

Based on the table above, it can be seen that the KaiserMeyer-Olkin (KMO) value obtained is 0.715 which means $>0.5$ and the value of Bartlett's Test obtained is 0,000 which means it is smaller than 0.5 so it can be concluded that factor analysis techniques in research this is feasible to do and analyze further.

\section{MSA (Measure of Sampling Adequacy)}

From the calculation of the MSA value obtained from the anti-image correlation. of the 24 indicators statement has a value of MSA (Measure of Sampling Adequacy) of more than 0.5 so that all indicators totaling 24 statements in factor analysis have the expected correlation so that they meet the test requirements for factor analysis and can be further analyzed.

\section{Community}

Communalities are values that are formed to find out how strong the factors that influence the shopping shift are influenced by the factors that will be formed later. Communal values have Extraction value $>0.5$ so it can be concluded that all indicators fulfill communal requirements and can be used to explain factors.

\section{Total Variance Explained}

Total Variance Explained is used to determine how many factors will be formed by determining the value in Total Initial Eigenvalues must have a value of at least 1,000.

Based on the table below, it can be seen that the component or factor that has a value of Total Initial Eigenvalues $>1,000$ is a component or factor 1 to component or factor 8 where the cumulative total percentage that can be explained by the eight factors is $73.68 \%$. 
TABLE II. TOTAL INITIAL EIGENVALUES

\begin{tabular}{|c|c|c|}
\hline \multirow[b]{2}{*}{ Component } & \multicolumn{2}{|c|}{ Initial Eigenvalues } \\
\hline & Total & $\begin{array}{l}\text { Cumulative } \\
\text { Percentage }\end{array}$ \\
\hline 1 & 5,566 & $23,190 \%$ \\
\hline 2 & 3,076 & $36,006 \%$ \\
\hline 3 & 2,021 & $44,425 \%$ \\
\hline 4 & 1,795 & $51,904 \%$ \\
\hline 5 & 1,587 & $58,517 \%$ \\
\hline 6 & 1,333 & $64,07 \%$ \\
\hline 7 & 1,160 & $68,90 \%$ \\
\hline 8 & 1,146 & $73,67 \%$ \\
\hline 9 & 0,871 & $77,03 \%$ \\
\hline 10 & 0,750 & $80,43 \%$ \\
\hline 11 & 0,638 & $83,09 \%$ \\
\hline 12 & 0,588 & $85,53 \%$ \\
\hline 13 & 0,547 & $87,81 \%$ \\
\hline 14 & 0,466 & $89,76 \%$ \\
\hline 15 & 0,429 & $91,55 \%$ \\
\hline 16 & 0,393 & $93,18 \%$ \\
\hline 17 & 0,352 & $94,65 \%$ \\
\hline 18 & 0,329 & $96,02 \%$ \\
\hline 19 & 0,257 & $97,09 \%$ \\
\hline 20 & 0,214 & $97,98 \%$ \\
\hline 21 & 0,171 & $98,69 \%$ \\
\hline 22 & 0,159 & $99,36 \%$ \\
\hline 23 & 0,089 & $99,73 \%$ \\
\hline 24 & 0,064 & $100 \%$ \\
\hline
\end{tabular}

\section{Scree Chart Plots}

The scree plot graph is a graph that shows the number of factors that can be formed following an explanation of the previous Total Variances Explained used to determine the intersection of the $\mathrm{X}$ axis and $\mathrm{Y}$ axis of the component or factor 1 with Total Initial Eigenvalues.

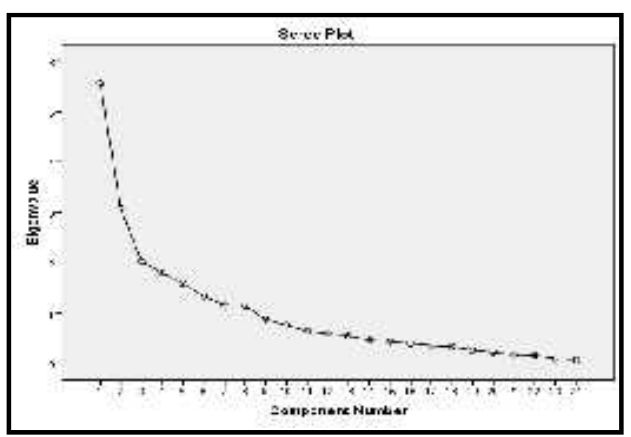

Based on the picture above, it can be seen that the component or factor 1 to component or factor 8 (lines from the component axis numbers 1,2,3,4,5,6,7 and 8) are still above 1 (Y axis) so the eight factors will form new factors later.

\section{Grouping and Giving Factor Names}

The group of factors from the available variable indicators can be determined based on the table on the results of the Rotated Component Matrix calculation, then it can be determined between variable indicators which will later enter which factors of the eight previously formed factors by seeing which correlation value is the largest.

\section{DISCUSSION}

The discussion conducted in this study was conducted to determine the results of the calculation of factor analysis methods so as to form several influential new factors. The results of the calculation of the Kaiser- Meyer-Olkin (KMO) value obtained in this study amounted to 0.715 which means> 0.5 and the value of Bartlett's Test obtained 0,000 which means less than 0.5 so it can be concluded that the factor analysis technique in this study is feasible to be carried out and analyzed further.

1. Then the 24 indicators of statements originating in the 8 original variables submitted have a value of MSA (Measure of Sampling Adequacy) of more than 0.5 so that all indicators totaling 24 statements in factor analysis have the expected correlation so that they meet the test requirements for factor analysis and can be analyzed Furthermore. Then on the results of the calculation of the output of Total Variance Explained, it can be seen that the component or factor that has the value of Total Initial Eigenvalues > 1,000 is the component or factor 1 to component or factor 8 where the cumulative total percentage which can be explained by the eight factors is $73.68 \%$.

2. From the results of the calculations obtained, it can be determined from all variable indicators that it will enter into which factors later can be seen in the correlation value of the Rotated Component Matrix calculation so that it can be grouped as follows:

a. Factor 1, each name of the extracted variable indicator leads to different factors, but it is seen from the indicator variable which has the highest factor loading value so this factor 1 is named factors influencing the nature of goods.

b. Factor 2, each name of the extracted variable indicator leads to the same factor so it doesn't need to use which loading factor has the highest value in naming factors so that factor 2 is named the Effect of Price factor.

c. Factor 3, each name of the extracted variable indicator leads to different factors but almost has similarities, and has the highest factor loading value so that factor 3 is named the factor of Effect of Failure in Service.

d. Factor 4, each name of the extracted variable indicator leads to different factors, but has the highest factor loading value so this factor 5 is named the Reliability Effect Factor. 
e. Factor 5, each name of the extracted variable indicator leads to different factors, but has a value the highest factor loading so that factor 5 is named the Influence factor.

f. Factor 6, each name of the extracted variable indicator leads to the same factor, therefore this factor 6 is named the Influence factor.

g. Factor 7, each name of the extracted variable indicator leads to different factors, but has the highest factor loading value and therefore a factor 7 This is named the Influence Factor.

h. Factor 8 consists of only one variable indicator, which leads to only one factor, so this factor 8 is named the location proximity effect factor.

\section{CONCLUSIONS AND RECOMMENDATION}

\section{Conclusion}

There are 8 components or factors that have a value of Total Initial Eigenvalues $>1,000$ that is a component or factor 1 to component or factor 8 so that a new factor is formed where the cumulative total percentage that can be explained by the eight factors is $73.68 \%$.

\section{Recommendation}

1. It is recommended that Minimarket 212 Mart add more variety of products sold to increase the attractiveness of buyers.

2. Minimarket 212 Mart should be able to add new branches in strategic locations.

\section{REFERENCES}

[1] Amanah, D. (2017). Perilaku Store Switching dalam Berbelanja Online. Forum Manajemen Indonesia (FMI 9).

[3] Hati SW dan Parlewenti, N. (2017). Analysis of Pricing a Effect to Customer Satisfaction and it's Affected to Customer Loyalty In Puri Batam Minimarket. Jurnal AdBispreneur, 53-68.

[5] Julianita, W. (2011). SPSS vs LISREL Sebuah Pengantar Aplikasi untuk Riset . Jakarta: Salemba Empat.

[6] Kasmadi, s. (2014). Panduan Modern Penelitian Kuantitatif . Bandung : Alfabeta.

[7] Kiel, D. L. (2005). Moral Intelligence. Pearson Education, Inc. Prentice Hall.

[8] Kotler, A. (2008). Pengaruh Kualitas Produk, Merek dan Desain terhadap Keputusan Pembelian Sepeda Motor Yamaha Mio. Journal EMBA Vol.1 No.3.

[9] Munir. (2011). Analisis Pengaruh Retailing Mix terhadap Keputusan Pembelian pada Minimarket Permata Di Kecamatan Balapulang.

[10] Spacey, J. (2017). 9 Type of Brand Switching. From https: // simplicable.com/new/brands witching.

[11] Sugiyono. (2014). Metode Penelitian Kuantitatif Kualitatif dan R\&D. Bandung: Alfabeta.

[12] Utami, C. W. (2010). Manajemen Ritel : Strategi dan Implementasi Ritel Modern. Jakarta: Salemba Empa 